\title{
Research on the Development of Macau's Public Housing Policies
}

\author{
Yichen Feng, Yiyang Li \\ Faculty of Innovation and Design, City University of Macau, Macau, China \\ Email: yiyangli327@gmail.com
}

How to cite this paper: Feng, Y. C., \& Li, Y. Y. (2021). Research on the Development of Macau's Public Housing Policies. Current Urban Studies, 9, 804-812.

https://doi.org/10.4236/cus.2021.94047

Received: November 4, 2021

Accepted: December 13, 2021

Published: December 16, 2021

Copyright $\odot 2021$ by author(s) and Scientific Research Publishing Inc. This work is licensed under the Creative Commons Attribution International License (CC BY 4.0).

http://creativecommons.org/licenses/by/4.0/

\section{Open Access}

\begin{abstract}
With the acceleration of urbanization, major cities are facing two problems, housing shortage and high housing prices. In particular, it is difficult for low-income groups to obtain affordable housing, which has become an obstacle to urban development. The concept of public housing has appeared in Macau since the 1920s, gradually forming a set of public housing policy systems with "public housing as the mainstay and economic housing as the supplement". This paper combs the development history and current situation of Macau's public housing policies. The main purpose of this article is to explore how to meet the basic housing needs of low-income groups in a modern city with high density and high housing prices through the study of public housing policies in Macau. In particular, areas with high population density and high housing prices like Macau have more typical effects. The method of the article is to collect the Macau public housing policies in the official website, consultation documents, and policies addresses, in addition, to summarize the development policies of Macau public housing in different periods. Public housing in Macau has always received great attention from local people and leaders, and the government has actively intervened to form a unique public housing system. However, after research, we found that the previous research on Macau's public housing policies had certain loopholes in the construction, application, and loan of public housing in Macau, sometimes it did not reflect the actual value of public housing. In addition, the development of public housing in Macau is closely related to the economic situation and public health incidents. For example, in the SARS and financial crisis, there has been retrogression. The public housing policies are relatively weak compared to other rigid policies. The novelty of the article is that it divides the complicated Macau public housing policies into 5 stages, so as to better grasp the development process of Macau public housing.
\end{abstract}

\section{Keywords}

Macau, Public Housing, Policies 


\section{Introduction}

Macau is a cramped place with a large population and tight housing. At the same time, house prices remain high. The housing demand of urban low-income people can not be reasonably guaranteed for a long time, which has become a problem that should not be ignored.

Macau is a city with a special historical background. Among the industries in Macau, the tertiary industry is relatively developed, but the categories are not complete. It mainly focuses on tourism and gambling, accounting for $51.3 \%$ of the tertiary industry (Zhang et al., 2000).

Starting from the construction of a batch of simple low-rent bungalows in 1928, the Macau government began to develop public housing, and gradually formed a set of public housing policy systems in subsequent explorations. After more than 80 years of development, Macau's public housing policies have achieved some results and experience. Therefore, this paper will study the development process of public housing in Macau, and summarize the success and shortcomings of public housing policies in Macau, hoping to provide enlightenment for the formulation of public housing policies for the city with high density and high house prices. In previous studies, there are many studies on public housing in Hong Kong, but few studies on public housing policies in Macau. This paper hopes to fill this gap and studies Macau's public housing policies from the perspective of policies formulation and implementation. Our research at this stage focuses on Macau policies documents without actual data support. We hope it can be supplemented in subsequent research.

\section{Data Sources and Methods}

The information comes from the Macau Special Administrative Region Sandwich Class Housing Plan Public Consultation Document, Macau Special Administrative Region Public Housing Development Strategy 2010-2020, and the Policy Address of the Chief Executive of the Macau Special Administrative Region from 2000 to 2021 . The data on Macau's population, area and density are from the official website of the Macau Statistics Bureau and Macau Government Housing Bureau. The article combines theoretical research and demonstration of policies to analyze Macau's public housing policies in different periods.

\section{Development History and Current Status of Public Housing in Macau}

The Macau Special Administrative Region is located in the south of China, on the west bank of the Pearl River Delta. It consists of the Macau Peninsula and the two islands of Taipa and Coloane, with a land area of 32.9 square kilometers. In 2019, its total population is approximately 682,800. Since the available land area is not much, the population density of Macau is also high. According to statistics, the population density of Macau reached 20,400 people per square kilo- 
meter at the end of 2019, and the population density is still on the rise. The extremely high population density, scarce available land and special historical institutional background have promoted the coexistence of "public housing and private buildings" in the housing market in Macau. Public housing has played an important role in solving the housing problem of the poor and low-income people.

The development of public housing in Macau can be divided into five stages: the initial stage of public housing in the 1920s, the development stage in the 1960 s to 1970 s, and the mature stage from the 1980 s to the end of the $20^{\text {th }}$ century, the stagnation and recovery stage of public housing development from 2000 to 2010, and the perfection stage from 2011 to 2020. At present, the public housing in Macau is mainly public housing and economic housing. The lease of social housing or the purchase of economic housing must be carried out according to the general bidding, except in exceptional circumstances. These two housing policies are also the key to the whole public housing policies (Jiang, 2009).

\subsection{The Initial Stage of Public Housing (1920s)}

During this period, the Macau government first made a clear definition of social housing: social housing refers to urban real estate or independent units that are managed by the Housing Bureau and allocated to families or individuals in compliance with the law for residential purposes. The origin of social housing in Macau is to provide relief to the victims. On August 25, 1928, a dilapidated slum village at Taishan District in Macau was destroyed by fire. The following year, the government rebuilt a batch of simple low-rent bungalows in the original location of the slum village. Poshafang came to resettle these victims and became the first public housing village in Macau. From this, Macau's social system began to develop. In 1948, the Governor of Macau promulgated the Macau Order 3 No. 4809 and established the Civilian House Management Ordinance to specifically regulate the management of the civilian housing estates of Liangfang (Li, 2019), and designated the civilian housing estates of Liangfang to be leased to the residence of the Chinese and Portuguese poor in Macau.

\subsection{The Development Stage of Public Housing (1960s to 1970s)}

From 1960s to 1970s, there were more than 300 public houses funded by the government or aid organizations, private charities, religious and social assistance groups (Lou, 2008), the houses were successively provided to poor or low-income families in the form of leasing. By 1984, there were 804 social housing units. With the continuous development of society and economy, some of these houses have been demolished. Among them, Mrs. Luo Bixin Building and Ka Cuili Building were converted into residential housing for the elderly, and elderly service centers were established. Provide services for the elderly. 40 years after the promulgation of the Civilian House Management Ordinance, Decree No. 69/88/M Social Housing Law was promulgated on August 8, 1988 to regulate the distribution, leasing 
and management of social housing in Macau. From the completion of the first batch of 411 public housing units in Macau in 1929, until the economic housing was first accepted by citizens in the form of general applications in accordance with the law in August 1995, Macau only used social housing for lease at that time to solve the housing problem of economically disadvantaged families.

\subsection{The Mature Stage of Public Housing (1980-1999)}

Public housing: Since the 1980s, Macau's economy has developed rapidly. At that time, Macau's industrial level reached its heyday. This meant that a large amount of labor was needed to support the development of industry. As a result, the number of immigrants from Guangdong and Fujian regions increased greatly, in response to social housing. With the trend of diversification of demand, the development of public housing in Macau has entered a new stage.

In terms of public housing, according to government statistics, the period from 1985 to 1992 was a period of concentrated public housing construction, during which the largest number of social housing estates were completed, with 1492 residential units, of which the largest public housing estate is Wangxia civilian New Village. It was completed in 1988 and continued to provide low-income people with housing in the form of leasing. By distributing social housing to eligible residents at low rent, the government has helped the lowest floor residents to move into new buildings with good conditions.

Economic housing: In 1980, the government introduced the Economic Housing Law. The law gave low-income people the opportunity to buy houses at lower prices than private developers. These houses are of good quality and the community facilities are also complete, including schools, kindergartens, activity centers, and shops, etc. Later, in 1984, the Macau government introduced the Housing Development Contract Law (August 29, 2011 by Law No. 10/2011 Economic Housing Law repealed) to alleviate the lack of local housing and assist the development of the construction industry in Macau, Thereby stimulating the increase in housing supply to meet the actual housing demand in the region and adapt to the purchasing power of citizens. The sale model is similar to public housing, and it is carried out by way of open application. The relevant executive agencies were decentralized and managed by several different departments at the beginning. This situation developed into the coordinating management of public housing by the Department of Housing of Macau established in 1990. In 1995, the Department of Housing publicly accepted applications for the purchase of economic housing for the first time. The law requires applicants to be permanent residents of Macau who are at least 18 years old. They must not own real estate within 5 years of acquiring the public housing. They can only be resold 16 years after acquiring the public housing. Once public housing flow into the private housing market, the resale proceeds must be returned to the government at a certain rate.

Additionally, in order to improve the living environment of the wooden houses 
where a large number of immigrants live in Macau, the Macau government built a number of temporary housing centers from 1968 to 1992. Temporary housing centers were built for families who did not meet the requirements of social housing and economic housing. With the development of the times, many temporary housing centers have been demolished.

\subsection{The Stagnation and Recovery Stage of Public Housing Development (2000-2010)}

From 2000 to 2004, due to the dual impact of the SARS incident and the Asian financial turmoil, the development of public housing in Macau entered a period of stagnation. According to the social housing history column of the Macau Government Housing Bureau, it can be seen that there was no public housing during this period. After this period of time has passed, Macau's economy has gradually taken off, and the number of foreign workers has also increased. Inflation has led to rising prices of private housing, which has increased housing pressure for lowincome groups, although public housing has been restored during this period of time. The construction of Fai Chi Kei Social Housing (Kuaifu Building), Fai Chi Kei Social Housing (Kuaiyi Building) and Qingzhou Social Housing (Qingsong Building) have been completed successively. Besides, 400 units and 736 elderly units (houses specially prepared for the elder) have been provided, but there is still a supply gap in the housing market Phenomenon.

\subsection{Perfection Phase of Public Housing Development (2011-2020)}

In the short term (2011-2014), the government's policies are to fully carry out the development plan of "Public Housing Project of Macau", to build new public housing to solve the housing problem of the low-income group as much as possible, and to strengthen the management of public housing to prevent resource abuse. The Macau government conducts a survey on the income of low-income families every two years (Zhang, 2006). At the same time, we will strictly implement the exit mechanism of social housing wealthy households, and strive to create a benign public housing development atmosphere. When resources permit, the economic housing department will consider reopening the economic housing application, and adjust the distribution ratio of social and economic housing according to the actual situation, so that more low-income people who need to buy a home can obtain their own houses. The management of public housing includes direct and indirect management. The former is operated by the Macau government housing management organization, and the latter refers to the professional property company entrusted by the Macau government housing management organization through contract (Shen, 1999). It also advocates public participation, increases the transparency of consultation, and regularly releases information about public housing to residents.

In the medium term period (2015-2020), the government will shift its focus to the sustainable development of public housing, and is committed to coordinat- 
ing and promoting the healthy and sustainable development of the Macau real estate market. Establish a public housing land reservation system to cooperate with the economic planning of the new city. Take advantage of regional cooperation to expand the living space of Macau residents. Review the economic housing laws in a timely manner. While increasing the supply of public housing, focus on studying the regular opening of applications for public housing estates, improving the living environment and the quality of life of residents. Besides, analyze the impact of population aging on the demand and mode of public housing, and carry out long-term planning research on elderly apartments.

\subsection{Summary}

From the perspective of the above five development stages, the public housing policy in the first three stages has played an important role in solving the housing problem of low-income groups. However, in the fourth stage, the development of public housing policy faces a short episode, which worsens the housing problem. On the whole, the housing quality of public housing is constantly improving, the living environment is constantly rising, and the supporting facilities are constantly improving, from the simple and small bungalows to the standardized, well-equipped, and good-environment houses, and then to the focus on the elderly. The construction of human details reflects the public housing constructed with the concept of sustainable development. Secondly, in order for the government to sustain the development of the real estate market, He Yicheng, the administrative region of Macau, proposed in April 2020 in the 2020 Fiscal Year Policy Address to "reasonably construct the home ownership ladder", and in October of that year implemented the "sandwich class housing" public consultation. The attitude of the government plays a key role in the development of public housing policies, and the game between the economy and the housing market. The relationship between the government and the market also affects the government's decision-making. In general, it has experienced the process from "passive intervention" to "active intervention" and from "negative intervention" to "active intervention" (Table 1).

In 2000, it was made clear that the Macau government would find a balance between social housing, economic housing and private real estate market through the change of land grant policies, and then it was not until 2007 that chief executive He Hohua took the housing issue as the focus of governance again.

In the report of chief executive Cui Shian in 2010, he also paid great attention to the housing problem, adhere to the housing policies of "having a place to live and work in peace and contentment". In addition, let the people participate in the discussion and Research on the direction of housing policies.

In the Policy Address in 2021, it was further proposed to push forward the public housing construction in zone of the new city, followed by the qualification examination of the owners of economic housing, and finally proposed the orderly implementation of the stepped housing policies. 
At present, the public housing market in Macau presents a structure of "public housing as the mainstay and economic housing as the supplement". Social housing is a leased housing, and an economic housing is a private housing. According to the Housing Bureau, as of the end of 2019, there were 234,059 units of all houses built in Macau, of which a total of 51,232 units were social housing and economic housing, accounting for $21.9 \%$ of the total number of residential units in Macau, and 14,269 social housing units, accounting for approximately $6.1 \%$ of the total number of residential units, 36,963 economic housing units, accounting for $15.8 \%$ of the total number of residential units. It can be seen from the figure, at present, there is a huge imbalance between private buildings and public housing (Figure 1).

Table 1. The development history of public housing in Macau.

\begin{tabular}{|c|c|c|c|}
\hline Time & $\begin{array}{l}\text { Development } \\
\text { stage }\end{array}$ & Living environment & $\begin{array}{c}\text { Government } \\
\text { intervention } \\
\text { attitude }\end{array}$ \\
\hline $1920 s$ & Initial stage & $\begin{array}{l}\text { Simple and short bungalows with poor } \\
\text { environment and small area }\end{array}$ & $\begin{array}{c}\text { Passive } \\
\text { intervention }\end{array}$ \\
\hline $1960 s-1970 s$ & $\begin{array}{l}\text { Development } \\
\text { stage }\end{array}$ & $\begin{array}{l}\text { Improved environment and increased use } \\
\text { area }\end{array}$ & $\begin{array}{l}\text { Active } \\
\text { intervention }\end{array}$ \\
\hline 1980-1999 & Mature stage & $\begin{array}{l}\text { Standardization of public housing, } \\
\text { integrating commercial and public services }\end{array}$ & $\begin{array}{l}\text { Active } \\
\text { intervention }\end{array}$ \\
\hline $2000-2010$ & $\begin{array}{l}\text { Stagnation and } \\
\text { recovery stage }\end{array}$ & No significant changes & $\begin{array}{l}\text { Negative } \\
\text { intervention }\end{array}$ \\
\hline $2011-2020$ & $\begin{array}{l}\text { Perfection } \\
\text { phase }\end{array}$ & Equipped with more service facilities & $\begin{array}{l}\text { Active } \\
\text { intervention }\end{array}$ \\
\hline
\end{tabular}

Source: collected by the author.

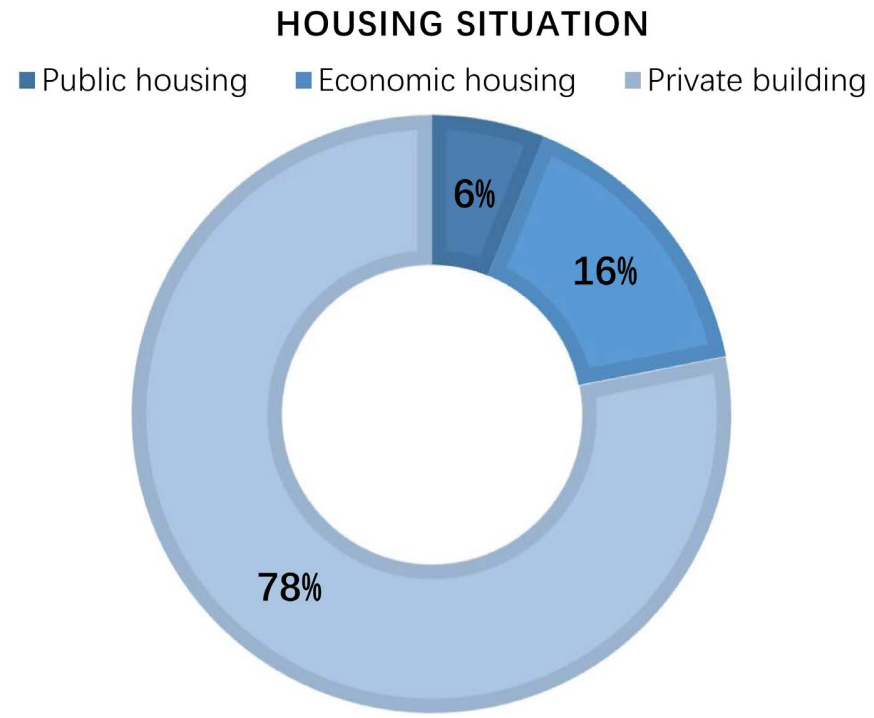

Figure 1. Statistics of the current housing situation in Macau (source: drawn by the author). 


\section{Conclusion}

In high-density modern cities, high housing prices and housing shortages are inevitable. In order to meet the basic housing needs of low-income groups, public housing policies promulgated by the government are necessary. In the 1920s, Macau introduced corresponding policies. Although it was originally designed to solve the housing problem of immigrants, it laid a good foundation for the development of public housing policies. The development of public housing in Macau has not been smooth sailing. There was retrogression in SARS and the financial crisis. However, the Macau government has been paying attention to the development of public housing policies for a long time, and developing and modifying measures to local conditions have given Macau's public housing policies certain advantages and characteristics.

The Macau government's attitude towards public service policies is not difficult to see from above. Under the active intervention, through the joint cooperation of several departments, the research on the development of public housing policies has achieved remarkable results, and it has indeed solved some of the difficulties of low-income people in buying houses. However, blindly building new public housing is not a permanent solution. The government should establish a completely closed-loop system from construction, application, loan, and expulsion of non-compliance. At the same time, the Macau government is launching a text of consultation opinions on sandwich class housing, and issuing corresponding policies for different income groups to protect their housing and form a stepped housing.

Through the research, it is found that public housing is a public policy with the welfare nature. At the beginning, it was formed only to solve specific problems, such as the housing problem of immigrants in Macau. After economic development, urban expansion, the shortage of land resources and the rise of land value have led to the increase in house prices. At this time, housing is a common problem faced by all the people. Public housing has gradually changed from a decree to a series of policies and measures. As a high welfare city, Macau's public housing has always been the focus of the government, which started earlier and developed more comprehensively. Through the research, it is not difficult to see that public housing, as a public policy with the welfare nature, does not develop steadily. In the event of the major economic crisis and major public health time, there will be drastic changes, and this change is usually backward. At the same time, public housing involves many interests, and all links of construction, application and loan can not guarantee complete fairness and justice. Today, public housing is no longer a simple government action, but the result of the cooperation of the government, developers and people from all walks of life. The government is still the leader. The government should carry out Macau policy-making and consultation texts and supervise the operation of all links at the same time. 


\section{Conflicts of Interest}

The authors declare no conflicts of interest regarding the publication of this paper.

\section{References}

Jiang, Z. W. (2009). Research on Improving Macau's Public Housing Policy. Master's Thesis, Huazhong University of Science and Technology.

https://kns.cnki.net/KCMS/detail/detail.aspx?dbname=CMFD2012\&filename $=1011276$ 172.nh

Li, J. (2019). Research on the Analysis and Evaluation of the Centralized Public Space of the Public Housing Complex in Macau. Master's Thesis, Huaqiao University.

https://kns.cnki.net/KCMS/detail/detail.aspx?dbname=CMFD202001\&filename $=10196$ 26271.nh

Lou, S. H. (2008). Housing Policy Orientation in Macau: From Safety Net to Moderate Welfare. Administration, 21, 266.

Shen, Z. C. (1999). Low-Cost Housing in Macau: Social Housing. China and Foreign Real Estate Herald, 24, 17.

Zhang, N. (2006). Macau's Public Housing Policy: "Households Are Suitable for Home". China Real Estate, 3, 73.

Zhang, Y. G., Han, Z. L., \& Luan, W. X. (2000). A Preliminary Study on the Characteristics of Macao's Economic Development and Industrial structure. Human Geography, $15,30-34$. 